\title{
Experiential Learning as Learner Centered Approach (LCA) in English Language Classroom
}

\author{
Andrew Philominraj ${ }^{1}$, Maria Graciela Badilla Quintana ${ }^{2}$, Rodrigo Arrellano ${ }^{3}$, Ranjeeva Ranjan ${ }^{3, *}$ \\ ${ }^{1}$ Department of Languages, Faculty of Education, Universidad Católica del Maule, Talca, Chile \\ ${ }^{2}$ Educational Informatics and Knowledge Management Unit, Universidad Católica de Santísima Concepción, Concepción, Chile \\ ${ }^{3}$ Department of Educational Foundation, Faculty of Education, Universidad Católica del Maule, Talca, Chile
}

Received September 27, 2020; Revised November 21, 2020; Accepted November 29, 2020

\section{Cite This Paper in the following Citation Styles}

(a): [1] Andrew Philominraj, Maria Graciela Badilla Quintana, Rodrigo Arrellano, Ranjeeva Ranjan, "Experiential Learning as Learner Centered Approach (LCA) in English Language Classroom," Universal Journal of Educational Research, Vol. 8, No. 12A, pp. 7660 - 7667, 2020. DOI: 10.13189/ujer.2020.082552.

(b): Andrew Philominraj, Maria Graciela Badilla Quintana, Rodrigo Arrellano, Ranjeeva Ranjan (2020). Experiential Learning as Learner Centered Approach (LCA) in English Language Classroom. Universal Journal of Educational Research, 8(12A), 7660 - 7667. DOI: 10.13189/ujer.2020.082552.

Copyright $\bigcirc 2020$ by authors, all rights reserved. Authors agree that this article remains permanently open access under the terms of the Creative Commons Attribution License 4.0 International License

\begin{abstract}
English language has been enjoying a privileged status in India and occupies a vital place not only in the lives of people but also in Education. English stretches out and expands in all walks of life, from consumer packing to popular magazines, and has a great influence on economic development. Despite the importance of English, the reality of this language in India has not reached the heights of international standards. Efforts to make learners more competent in English language communication are a reality yet to be achieved as revealed in several studies. The current study proposes experience, which is a basis of fundamental and natural learning available to everyone that can be utilized towards the learning of the language by students. In addition, the language teachers are invited to recognize the in-built capacity of the experience in students to foster their learning process. This article, an exploratory study through a quantitative method was carried out among a group of students, in several schools, in the city of Chennai. The results revealed the significance and the utility of Experiential learning, as one such engaging method based on Learner Centered Approach to the learning of English as a second language
\end{abstract}

Keywords Experiential Learning, Learner Centered Approach, Language Classroom, English as a Second Language

\section{Introduction}

The foundation of Experiential Learning can be traced back to Dewey's Progressive Approach, Lewin's Social Psychology, Jean Piaget's work on Developmental Cognitive Psychology, Kelly's Cognitive Theory of Personality, and to Humanistic Psychology of Maslow and Rogers as cited in Kohonen [13]. Experiential Learning is an educational method whose roots go a long way down history [14]. The interest in learning by experience or constant practice repeatedly gained and lost its influence gradually in educational theories. In recent times, research in this field has gained momentum and proves to be an alternative to standard methods [16]. In Experiential Learning, immediate personal experience is seen as the focal point for learning, giving "life, texture, and subjective personal meaning to abstract concepts and at the same time providing a concrete, publicly shared reference point for testing the implications and validity of ideas created during the learning process" [14].

The theoretical background of Experiential Learning leads to an understanding of the term 'experience'. Experiences from a macro understanding are perceptions, impressions, which are positive, impressive, and unusual. At a micro level, experience helps to gain an enriching understanding of life, which leads to the reconciliation of internal and external reality. This enriching understanding, both at the macro and micro level, brings in a change to our personality resulting in the formation of knowledge. 
Experience, which is a basis of fundamental and natural learning, is available to everyone. It does not require software or technological equipment to support learning. It is not expensive either. All that is required is the opportunity to reflect and think, either alone or in the company of other persons. The metacognitive process involved and the creation of a meaningful learning experience make this form of learning more effective and deep-rooted.

The advantage of the Experiential Learning method is that it enriches the learning of a second language due to the underlying fact of the specific approach of motivation and psychological contribution. An individual learns through subjective experiences and personal involvement, which are more easily remembered than neglected. Another important fact about Experiential Learning is that besides any particular subject or field of study, an emphasis is laid on the importance of holistic personal development. Experiential Learning style is often understood simply as "trying things out". The method of Experiential Learning is justified because "a) it facilitates personal growth; b) it helps learners to adapt to social change; c) it takes into account the differences in learning ability; and d) it responds to learners" needs and practical pedagogical considerations" $[13,14]$.

\section{Literature Review}

\subsection{Conceptual Clarification Models of Experiential Learning}

"Experiential Learning is the sense-making process of active engagement between the inner world of the person and the outer world of the environment" [2]. Oxford Dictionary [18] defines experience as "the fact of being consciously the subject of a state or condition; of being consciously affected by an event; a state or condition viewed subjectively; an event by which one is affected; and knowledge resulting from actual observation or from what one has undergone". These definitions of experience connect both the action and the act of thinking about the action. Indeed, Cuffaro [6] emphasized, "Action and thought are not two discrete aspects of the experience. It is not to undertake any activity and then at its end to contemplate the results. What is stressed is that the two must not be separated, for each informs the other" [2].

There are two aspects involved in the process of Experiential Learning such as experience and learning. Both these aspects take into consideration the learner who is involved in the process and the object, which is the process of learning and the experience involved. This indicates that one must be attentive to the learner and at the same time be conscious of the learning process, which is in the act. The human person is a complex unity of senses, intellect, and spirit. The learning process becomes efficacious and result oriented when the totality of the learner is in harmony. The senses are perceptive and receptive, a stimulus coming from external objects or reality is received and is ordered according to the needs of the human subject who desires to learn. This is always a dynamic process, wherein the verification between the data received and verified is continuous since learning by experience is progressive.

As mentioned above, in the process of learning, two things are expected to be considered. First is the human person who is in the process of learning and the second is that learning always begins in relation to other human persons. It could be said that learning is both a subjective as well as inter-subjective process. Experiential Learning is above all a learning process that brings into play a variety of subjects each with their unique experiences and ways of experiencing. Each one seeks meaning and the meaning is found above all in relation to others' experiences. Seeking a linguistic meaning pre-supposes an inter-subjective meaning, which takes into account each one's situation. Even if the linguistic meaning is objective, it reveals the subject.

Helen Keller discovered learning by the successive touches made on her hand by her teacher conveying the names of objects [5]. This first experience of discovery marked by profound emotion led to the rise of interest and desire to learn, which paved way for her to learn the names of twenty objects in a short period. This marked an incredible career of learning for Helen. The example of Helen Keller indicates that language develops in different ways making each Experiential Learning unique.

It is important to highlight another aspect of experiential learning, which reveals that people just do not learn from experience, rather reflecting on their own experiences. When the learner is the subject of experience then learning becomes fundamental and thus leads to the success of any learning process. This process is learning by doing and thus developing their own understanding. In any teaching-learning context, the role of a teacher or facilitator is significantly important and is also central to how the classroom environment evolves [23]. A facilitator hence is invited to always seek ways to enable learners to achieve their goals. This can be carried out by exposing learners to an appropriate environment, introducing them to activities that would challenge them, and develop understanding leading to meaningful conclusions. A learning activity is a means to an end, not an end in itself. The main aim of Experiential Learning is to make learning memorable and personal. Any ideal task will engage, stimulate and challenge learners to achieve success in learning

\subsection{Models of Experiential Learning}

The conceptual development of Experiential Learning has its origin in the late nineteenth and beginning of the 
twentieth century. Kolb developed the modern theory of experiential learning, drawing heavily on the work of John Dewey, Kurt Lewin, and Jean Piaget [7]. Kolb's Theory of Experiential Learning is considered to be one of the most important experiential learning theories, particularly his experiential learning model. This theory is based on learning through experiences and learners basing their choice on past experiences [22]. In the words of Kolb [14], "Learning is the process whereby knowledge is created through the transformation of experience". Kolb [14] proposes the following Experiential Learning cycle model, which is widely accepted in the field of learning.

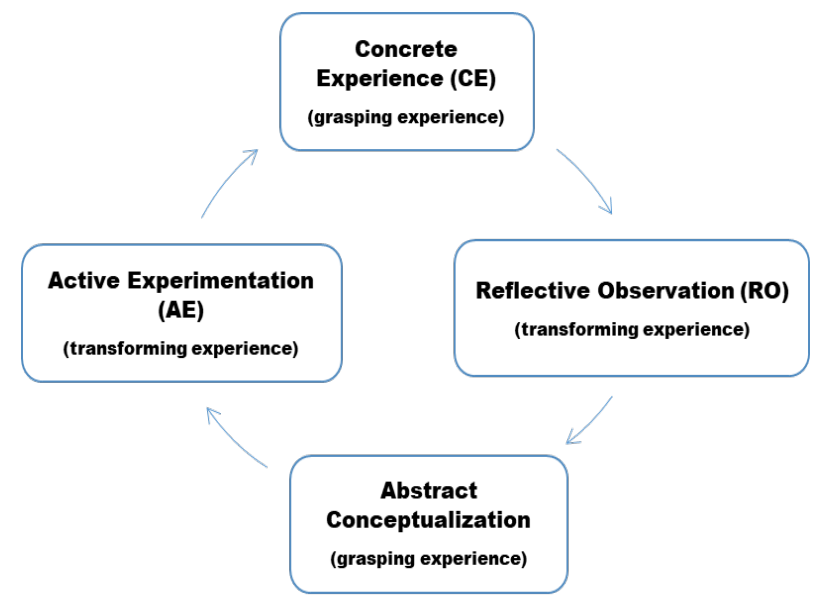

Figure 1. The Experiential Learning Cycle [14]

In the above model, Kolb [14] refers to $\mathrm{CE}$ as experiencing, $\mathrm{RO}$ as reflecting, $\mathrm{AC}$ as thinking, and $\mathrm{AE}$ as acting. According to him, learning arises from "the resolution of creative tension among these four learning modes". The aim of cyclic advances from an impulse to judgment and knowledge to observations is that it makes a distinction between experiences such as composed interaction and reflective thought [17]. Kolb uses the term "reflective thought" to describe the process through which people learn from their observations and personal experiences [20]. In terms of language teaching, Experiential Learning leads us to task based learning, which proposes that language-learning syllabi might best be organized around tasks rather than topics or grammatical forms. By using English as the medium in content-based instruction and relying on a "Natural Approach" of exposure to roughly-tuned scaffolded input, students can learn the language inductively rather than focusing on language forms or grammatical structures. Rod Ellis [9] might refer to such an approach as one that concentrates on practice with various language functions as learners work collaboratively to solve problems, create products, or perhaps prepare presentations, progressing naturally towards language fluency and accuracy.

Task-based teaching is an effective way of teaching, with which learners are made to internalize grammatical accuracy by using language in a real-life situation, rather than forcing them to follow conscious rules leading to externalized language. In Prabhu's model, the teacher acts as an important bridge between the learners' current ability and their mastery of new knowledge. Through inductive learning during task-based activities, learners make great leaps towards new learning.

N. S. Prabhu in the Bangalore Project in India [19] used a Task Based Learning (TBL) curriculum with young learners focus. For the young learners who participated in this project, Scaffolding and TBL were used while studying mathematics, geography, or other types of problems in English. Experiential Learning in the Bangalore project had a general education focus, but it also used English as the medium of instruction. Therefore, language and content-based instruction were considered effective tools for learning. The main idea of a task in this Project was that young learners focused on the meaning of the content rather than on grammatical form. "The learning goals and language outcomes were not specifically linked to language accuracy" [3]. Prabhu [19] argues that, at least in the context of this school-based project, "the most effective teaching took place through activities that pushed the cognitive boundaries of the learners". The task framed was based on learners' experience, therefore; learning could take place in Prabhu's project, which led to an emphasis on Experiential Learning for learners.

The topic of Experiential Learning is a complex one with broad implications for young learners. Many competing theories of English language education resonate with Experiential Learning and task-based ideas. The activities used in Prabhu's project were by no means complete or exhaustive. The challenge of a teacher is to develop his or her own set of working task-based activities to spice up his or her lessons, motivate his or her students, and make their learning more meaningful and memorable.

Benjamin Disraeli as quoted in Beard and Wilson [2] states that "experience is the child of thought, and thought is the child of action - we cannot learn men from books". This particular quote of Disraeli though marks a division between theory and practice nevertheless draws attention to the need to think and learn through experience. His argument that we cannot learn men from books might be sustainable, yet there is a kernel of truth in his message. Experience is also a method of learning and given the fact of previous knowledge, the learner or a teacher will have their own imagination helping them to move faster. Experiential Learning includes an internal and external involvement of the thoughts and their recreational and leisure activities.

\section{Method}

The present research work was carried out in the city of 
Chennai in Tamilnadu, which was chosen primarily for its cosmopolitan nature. It is one of the largest metropolitan cities in India. Chennai is educationally forward with many private and public educational institutions.

\subsection{Participants}

The primary data was collected through a survey from 504 students with different pretested questionnaires, i.e. questionnaires used in the pilot study of this project. The survey was conducted in ten higher secondary schools in Chennai city. These schools were selected due to their academic performance in the school leaving examination. The details of the participants are mentioned below in Table 1.

Table 1. Details of the participants

\begin{tabular}{|c|c|}
\hline $\begin{array}{l}\text { Number of } \\
\text { participants }\end{array}$ & 504 \\
\hline Age group & $16-18$ years \\
\hline Grade & 11th standard \\
\hline Gender & $\begin{array}{l}\text { The data was not collected concerning } \\
\text { gender }\end{array}$ \\
\hline School & 10 private institutions \\
\hline City & Chennai, India \\
\hline Year of survey & 2016 \\
\hline
\end{tabular}

\subsection{Research Instrument(s)}

The survey questions for learners contained topics concerning parent's educational background, economic status, and learners' interest in learning English. The questionnaire also tried to find out learners' weekly hours of English classes, years in learning English, and the amount of time spent in practicing English. It also carried questions to find out their exposure to the environment and Experiential Learning practices. Learners' expectations of teachers' activities towards English teaching and their views and opinions as the best practices for teaching and learning of English were other topics contained in the questionnaire. The majority of the questions in the teachers' questionnaire contained were mostly similar to the topics mentioned in the learners' questionnaire except for a set of questions that were based on teachers' assumptions on Learner Centered Approach. Teachers' and learners' questionnaires contained forty one and forty three questions respectively.

The questions used in this study are of closed-ended model. Teachers and learners were allowed to choose one of the alternatives. Data analysis was carried out using MS office and SPSS software tools.

As mentioned earlier, a pilot study was carried out among 45 students belonging to two different private schools in the city of Chennai. This was done to assess the feasibility and verify the effectiveness of the questionnaire.

\subsection{Limitations of the Study}

The study was limited to the students of the 11th grade from private schools in the city of Chennai. The research could be taken up for the further study at public schools. The present research was confined only to Chennai city, as it is a well-represented cosmopolitan city in India, but there are also other cities where a good representation of people hailing from different ethnic and sociocultural backgrounds, could be considered for further research. Furthermore, this study was an exploratory and transversal study and perhaps a long-term longitudinal study could contribute further to gain in-depth knowledge on the use of Experiential Learning towards teaching and learning.

\section{Findings \& Discussion}

Table 2. Language Spoken at Home by the Sample Learners

\begin{tabular}{ccccc}
\hline SI. & Opinion & Frequency & Percent & CP \\
\hline 1 & English & 25 & 5.0 & 5.0 \\
2 & Tamil & 378 & 75.0 & 80.0 \\
3 & Telugu & 36 & 7.1 & 87.1 \\
4 & Malayalam & 28 & 5.6 & 92.7 \\
5 & Hindi & 21 & 4.2 & 96.8 \\
6 & Others & 16 & 3.2 & 100.0 \\
& Total & 504 & 100.0 & \\
\hline
\end{tabular}

Source: Field survey.

$\mathrm{CP}$ : Cumulative percent (in below tables, $\mathrm{CP}$ has been used for Cumulative percent)

Tamil is the official language in the State of Tamil Nadu and hence it is a widely spoken language. This is reflected in the data in Table 2 where about 75 percent of the sample learners speak Tamil, followed by Telugu speakers who amount to 7.1 percent, whereas Malayalam speakers are 5.6 percent. The other languages include Kannada, Urdu, Punjabi, Oriya, Marathi, etc. Those who speak English are registered as 5 percent, and this does not in any way influence the negativity of learning language, rather it shows the diversity when compared to other languages. It also reflects the language policy of the Government.

Table 3. Number of Years the Sample Learners Learning English

\begin{tabular}{ccccc}
\hline SI. & Opinion & Frequency & Percent & CP \\
\hline 1 & $0-1$ & 10 & 2.0 & 2.0 \\
2 & $1-2$ & 14 & 2.8 & 4.8 \\
3 & $2-3$ & 50 & 9.9 & 14.7 \\
4 & $4-5$ & 311 & 61.7 & 76.4 \\
5 & 5 and above & 119 & 23.6 & 100.0 \\
& Total & 504 & 100.0 & \\
\hline
\end{tabular}

Source: Field survey.

Table 3 suggests that 61.7 percent of the sample learners' learn English for about 4 to 5 years; this is 
followed by 23.6 percent who learn for more than 5 years etc. The data indicate that all the sample respondents spent several years learning the English language. It is clear from the learners' opinion that English occupies an essential part of their learning process.

Table 4. Sample Learners' Number of Hours of English Classes per Week

\begin{tabular}{ccccc}
\hline Sl. & Opinion & Frequency & Percent & CP \\
\hline 1 & $1-3$ & 53 & 10.5 & 10.5 \\
2 & $4-6$ & 394 & 78.2 & 88.7 \\
3 & $7-10$ & 43 & 8.5 & 97.2 \\
4 & 10 and above & 14 & 2.8 & 100.0 \\
& Total & 504 & 100.0 & \\
\hline
\end{tabular}

Source: Field survey.

Table 4 shows that 78.2 percent of the sample learners' have English classes for about 4 to 6 hours per week; whereas 10.5 percent have 1 to 3 hours weekly, 8.5 percent have 7 to 10 hours weekly and 2.8 percent have for more than 10 hours weekly. The purpose of language teaching is to ensure optimal input in sufficient quantity for the learners to profit from it. The weekly frequency of English classes has a major impact on learners in arousing their interest and helping them to find the learning of English attractive as mentioned in the previous tables.

Table 5. Number of Hours Spent Speaking English outside Class Hours by the Sample Learner

\begin{tabular}{ccccc}
\hline Sl. & Opinion & Frequency & Percent & CP \\
\hline 1 & $0-1$ & 110 & 21.8 & 21.8 \\
2 & $1-2$ & 193 & 38.3 & 60.1 \\
3 & $3-4$ & 111 & 22.0 & 82.1 \\
4 & 5 and above & 90 & 17.9 & 100.0 \\
& Total & 504 & 100.0 & \\
\hline
\end{tabular}

Source: Field survey.

Table 5 shows that about 60.1 percent of sample learners speak English for less than 2 hours a day while the rest of them speak for more than 3 hours. Speaking English outside the class hours is one way of putting into practice what is learnt in the class, which helps them to gain the knowledge of the language as well as foster learners' experience of participation with peers and others.

Table 6. Sample Learners on School Environment favoring learning English

\begin{tabular}{ccccc}
\hline Sl. & Opinion & Frequency & Percent & CP \\
\hline 1 & Always & 341 & 67.7 & 67.7 \\
2 & Often & 105 & 20.8 & 88.5 \\
3 & Rare & 29 & 5.8 & 94.2 \\
4 & Never & 7 & 1.4 & 95.6 \\
5 & No opinion & 22 & 4.4 & 100.0 \\
& Total & 504 & 100.0 & \\
\hline
\end{tabular}

Source: Field survey.
The school environment plays an important role in learning English and is indispensable to learn it. This fact can be supported from the survey result, as shown in Table 6 , in which 67.7 percent opined that the school environment always favors English language learning followed by 20.8 percent who responded with the option of often. Thus in total 88.5 percent responded positively that the school environment favors their learning process. The school environment is not only conducive but also a vital source of input for learners who are motivated to participate actively in the learning of the English language.

Table 7. Sample Learners on Speaking in English to their Friends

\begin{tabular}{ccccc}
\hline Sl. & Opinion & Frequency & Percent & CP \\
\hline 1 & Always & 114 & 22.6 & 22.6 \\
2 & Often & 200 & 39.7 & 62.3 \\
3 & Rare & 125 & 24.8 & 87.1 \\
4 & Never & 47 & 9.3 & 96.4 \\
5 & No opinion & 18 & 3.6 & 100.0 \\
& Total & 504 & 100.0 & \\
\hline
\end{tabular}

Source: Field survey.

Table 7 clearly shows that 22.6 percent responded always, 39.7 percent as often and 24.8 replied saying rare in speaking English to their friends. 62.3 percent of sample learners have responded using English to speak to their friends. The result highlights that the learners use their previous English language knowledge to communicate, which indicates experiential learning. The remaining students if introduced to this method of learning will certainly develop language learning.

Table 8. Sample Learners on Teachers Using Mother Tongue while Teaching English

\begin{tabular}{ccccc}
\hline Sl. & Opinion & Frequency & Percent & CP \\
\hline 1 & Always & 63 & 12.5 & 12.5 \\
2 & Often & 49 & 9.7 & 22.2 \\
3 & Rare & 66 & 13.1 & 35.3 \\
4 & Never & 279 & 55.4 & 90.7 \\
5 & No opinion & 47 & 9.3 & 100.0 \\
& Total & 504 & 100.0 & \\
\hline
\end{tabular}

Source: Field survey.

Table 8 suggests that only 22.2 percent of the sample learners have opined on the teacher speaking in mother tongue while teaching English, whereas 55.4 percent of them have said as never over their teacher speaking in mother tongue while teaching English. This response of the majority confirms the theory that "comprehensive input in quantity" $[14,8]$ of the target language helps learners to learn the language in a better way, which is also recognized 
and acknowledged by the learners.

Table 9. Sample Learners on Being Bilingual at the End of their Schooling

\begin{tabular}{ccccc}
\hline Sl. & Opinion & Frequency & Percent & CP \\
\hline 1 & Agree & 240 & 47.6 & 47.6 \\
2 & Strongly agree & 177 & 35.1 & 82.7 \\
3 & Disagree & 19 & 3.8 & 86.5 \\
4 & Strongly disagree & 10 & 2.0 & 88.5 \\
5 & No opinion & 58 & 11.5 & 100.0 \\
& Total & 504 & 100.0 & \\
\hline
\end{tabular}

Source: Field survey.

Table 9 shows that 47.6 percent of the sample learners have agreed, 35.1 percent of them have strongly agreed (both combined 82.7 percent) to the question on being bilingual (English and mother tongue) at the end of school. This exhibits their liking of two languages. This is favored by the environment in a country like India where several languages coexist and a reflection of the Government's bilingual formula policy to the learning of languages.

Table 10. Sample Learners on Experiential Learning Practices of their English lessons

\begin{tabular}{ccccc}
\hline SI. & Opinion & Frequency & Percent & CP \\
\hline 1 & Brainstorming & 87 & 17.3 & 17.3 \\
2 & Field trips & 78 & 15.5 & 32.8 \\
3 & Problem solving & 123 & 24.4 & 57.2 \\
4 & Translation & 94 & 18.7 & 75.9 \\
5 & Research & 122 & 24.1 & 100.0 \\
& Total & 504 & 100.0 & \\
\hline
\end{tabular}

Source: Field survey.

Table 10 is on Experiential Learning like brainstorming, field trips, problem solving, translation, and research. The response to this question is that 24.4 percent of them prefer problem solving, followed by 24.1 percent research, 18.7 percent translation, 17.3 percent brainstorming, and 15.5 percent field trips. The learners' preference for problem solving shows their conviction, as observed during the survey, over the experience gained in L1, which is brought into the learning of L2. "The second language learning process refers to the process in which a learner with the mastery of his or her mother tongue learns another language" [4]. Experience of L1 is naturally an 'input' to the learning of a second language.

Table 11. Sample Learners on the Best Approach for Learning English

\begin{tabular}{ccccc}
\hline Sl. & Opinion & Frequency & Percent & CP \\
\hline 1 & Teacher centered & 97 & 19.2 & 19.2 \\
2 & Learner centered & 407 & 80.8 & 100.0 \\
& Total & 504 & 100.0 & \\
\hline
\end{tabular}

Source: Field survey.
Table 11 shows the choice of the students on the best approach for learning English between Teacher Centered and Learner Centered. The Teacher Centered Approach consisting of lecture, recitation, textbook assignments, dictation, and vocabulary drills is preferred by 19.2 percent of the sample learners, whereas Learner Centered Approach (LCA) that mainly focuses on the method of Experiential Learning is preferred by 80.8 percent of the sample learners. Learner and learning are two essentials of Learner Centered approach. This approach considers vividly the relevance and meaningfulness of what learners are being asked to learn. This LCA approach, consisting of this particular method, is widely accepted by the respondents as they take into consideration the learners' needs, necessities, and aspirations. Such a method with its variety of activities contributes positively to the learning of English language.

This study has been an attempt to explore the significance and utility of experience towards the learning of the English language. Results from the learner's survey, as seen in the tables above throw light on the fact that learners' choosing to learn English has been done, both out of their own liking and out of interest. A similar observation has been found in another study by $\mathrm{Mc}$ Pherson-Geyser et al. [17], wherein they underline that Experiential Learning focuses on the promotion of the development of a learner's potential, building on his/her strengths and taking advantage of his/her talents. In addition, the learners are also well supported by their families in the language learning process. Learners' experience in learning does not rely on "taking up of the predetermined problem in a ritually defined setting" [12]. Learners' learning situation has been creative and exploratory, defined by themselves in consensus with teachers. A learner with a common objective, i.e. the desire to improve his or her knowledge of English, is what was observed from the results of the survey. Furthermore, it was witnessed that learners' interest has been on sharing knowledge through skill exchanges, with the teacher, environment and accepting the support from specialist resource persons that Ilich envisaged as coming from an "Educator at large". This finding is also in line with a study carried out by Rahman et al. [21] who mentions that people interact with the environment to grasp information and transform the information they acquired to concrete experience, and thus creating knowledge. Learning is not divorced from living; the outside world is not made to disappear from the classroom. Results gathered from the survey confirm, learner's experiences do not limit themselves to the classroom but go beyond, facilitating thus the content in becoming Input and favoring Interaction in this process of learning the language.

\section{Conclusions}

The idea of learning through experiences may seem 
self-evident but this remains a popular saying rather than a defined theory. In general, theories of learning, education, training, and development are carried out in isolation without any overall coherence. The novelty of Experiential Learning is that it acts as a knitting force bringing together learning theories and making them as one whole. In the learning of English, methods like Experiential Learning, which is Learner Centered Approach opens a new horizon providing the learner a new impulse of enthusiasm and courage towards a positive approach in language acquisition.

Experience and learning are closely interwoven and almost inseparable. In many respects, experience and learning mean the same thing, and thus Experiential Learning is a tautology or repetition of the same idea [2]. Learning must be based on learners' previous experiences; learners must have time to think about their experiences and reflect on them, and they must apply their new skills in real-life situations [10]. The results of the study clearly state that learning is the interaction between self and the external environment, summed up as experience. Harrison et al. [11] recalling Rogers's states, "There is growing consensus that experience forms the basis of all learning". Therefore exposing learners to Experiential Learning potentiates their process of acquiring a new language [1] as it involves the whole self of the learner as in learner-centered and helping him or her obtaining the needed success in language learning.

In today's globalized world, given the diverse nature of learners, it becomes essential to make language learning experiences attractive, motivating students towards liking the language leading them to be successful in learning of English language.

\section{Acknowledgements}

The author(s) received no financial support for the research, authorship, and/or publication of this research. Article contributing to FIC-BIP30.447.484-0.

\section{REFERENCES}

[1] Baker, A., Jensen, P. \& Kolb, D, "Conversation as Experiential Learning", Management Learning, vol. 36, pp. 411-427, 2005. DOI: 10.1177/1350507605058130.

[2] Beard, C. \& John Peter Wilson, Experiential learning: A practical guide for training coaching and education, Kogan Publishers, 2018.

[3] Cameron, L., Teaching languages to young learners, Cambridge University Press, 2002.

[4] Changyu Li, "A research on second language acquisition and college English teaching”, Journal of English Language Teaching, vol. 2, no. 4, 2009.
[5] Crow, L., "Helen Keller: Rethinking the problematic icon", Disability \& Society, vol. 15, no. 6, pp. 845-859, 2000. DOI: $10.1080 / 713662010$

[6] Cuffaro, H.K, Experimenting with the world: John Dewey and the early childhood classroom. Teachers College Press, 1995.

[7] Dixon, Nancy M.; Adams, Doris E.; Cullins, Richard, Learning Style. Assessment, Development, and Measurement, 1997.

[8] Dong-li, Z, "Krashen's input hypothesis and English classroom teaching", US-China Foreign Language, vol. 6, no. 9,2008 . https://wenku.baidu.com/view/ad766d2916888 $4868762 \mathrm{~d} 6 \mathrm{c} 5 . \mathrm{html}$

[9] Ellis, R., Task-based language learning and teaching, Oxford University Press, 2003.

[10] Enfield, R. P, Connections between 4-H and John Dewey's philosophy of education focus, University of California, 2001.

[11] Harrison, R., Reeve, F., Clarke, J., \& Hanson, A., Supporting lifelong learning: perspectives on learning, Routledge Falmer, 2002.

[12] Illich, I, Deschooling society, Calder\& Boyars Ltd, 1970.

[13] Kohonen, V., "Experiential language learning. Second language learning as cooperative learner education", In Collaborative language learning and teaching. (Ed.) David Nunan, Cambridge University Press, 1992.

[14] Kolb, D., Experiential Learning: Experience as the Source of Learning and Development, 2nd Edition, Pearson Education Inc., 2015.

[15] Krashen, S., Second language acquisition and second language learning. Prentice-Hall International, 1988.

[16] Kujalová, J., "Use of Experiential Learning in Teaching English as a Foreign Language". Unpublished thesis, Masaryk University, Czech Republic, 2005.

[17] Mc Pherson-Geyser, G., de Villiers, R., \& Kavai, P, The Use of Experiential Learning as a Teaching Strategy in Life Sciences. International Journal of Instruction, vol .13, no.3, pp. $877-894$, 2020. DOI: $10.29333 /$ iji.2020.13358a

[18] Oxford Dictionary, Compact oxford English dictionary of current English (Ed). Catherine Soanes and Sara Hawker, Oxford University Press, 2012.

[19] Prabhu, N.S., Second language pedagogy, Oxford University Press, 1987.

[20] Roberts, G. (2006). A philosophical examination of experiential learning theory for agricultural educators. Journal of Agricultural Education, vol. 47, no. 1, pp.17-29.

[21] Siti Nadhirah Abd Rahman, Arshad Abd Samad, Norlida Abu Bakar, "Exploring Learners' Perception on Improving Their Willingness to Communicate in English through Experiential Learning among Undergraduate Students," Universal Journal of Educational Research, Vol. 8, No. 1A, pp. 62 - 69, 2020. DOI: 10.13189/ujer.2020.081309.

[22] Sternberg, R. J., \& Zang, L. F, Perspectives on cognitive, learning, and thinking styles, Lawrence Erlbaum, 2000. 
[23] Wang, L, "Sociocultural learning theories and information literacy teaching activities in higher education", American

Library Association, vol. 47, no. 2, pp. 149-159, 2006. 